\title{
Heat stress mitigation strategies for beef cattle under intensive finishing in the Mexican dry tropics
}

\section{Zazueta-Gutiérrez, Ana G.; Romo-Valdez, Ana M.; Castro-Pérez, Beatriz I.; Ríos-Rincón, Francisco G.*}

Universidad Autónoma de Sinaloa. Facultad de Medicina Veterinaria y Zootecnia. Culiacán, Sinaloa, México

*Corresponding author: fgrios@uas.edu.mx

\begin{abstract}
Objective: Review the heat stress mitigation strategies in intensive cattle feedlots in the tropical region of México.

Approach: Beef cattle production is one of the principal activities of the agricultural sector; therefore, to maintain the inventory in intensive finishing pens, a considerable number of cattle are moved to geographic areas where climatic conditions are not always favorable for most of the year. High environmental temperature combined with relative humidity create heat stress conditions and consequently affecting the productive indicators by compromising the physiological stability of the cattle.

Implications: The improvement of housing conditions to mitigate the effects of heat stress in beef cattle in intensive finishing involves considering living space, available shade area, feeding and watering space that assure the cattle welfare during their stay in livestock production units.

Conclusions: Heat stress mitigation strategies in beef cattle during intensive finishing in practical conditions should contribute to animal welfare and the improvement of the productive indicators at the Mexican dry tropics.
\end{abstract}

Keywords: cattle, meat production, heat stress.

Gitation: Zazueta-Gutiérrez, Ana C., RomoValdez, Ana M., Castro-Pérez, Beatriz I., \& Ríos-Rincón, Francisco G. (2021). Heat stress mitigation strategies for beef cattle under intensive finishing in the Mexican dry tropics. Agro Productividad, 14(\#). https://doi. org/10.32854/agrop.v14i7.1874

Editor in Chief: Dr. Jorge Cadena Iñiguez

Estimated publication date: August 2021

This work is licensed under a Creative Commons Attribution-Non-Commercial 4.0 International license.

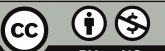

\section{INTRODUCTION}

In Mexico, beef cattle production represents one of the principal activities of the agricultural sector, due to its contribution to the supply of meat products, as well as its participation in the country's trade balance (Rubio et al., 2013; FIRA, 2019). The evolution of the world beef market and the competitiveness of the countries participating in it influence the dynamics of this activity (Magaña et al., 2020). In this sense, beef production in 2019 reached a historical maximum of two million tons, which is $2.4 \%$ higher compared to 2018; 86\% of the Mexican beef exports went to the United States. In this activity, the states of Veracruz, Jalisco, San Luis Potosí, Sinaloa and Chiapas stand out, producing 838,930 tons, this implies a contribution of $41.3 \%$ of the national total (SADER-SIAP, 2019). 
In northwestern Mexico, the Culiacán Valley, Sinaloa is located at $24^{\circ} 48^{\prime} 00^{\prime \prime} \mathrm{N}$ and $107^{\circ} 23^{\prime} 00^{\prime \prime} \mathrm{W}$ and $70 \mathrm{~m}$ asl; the average maximum temperature is $36^{\circ} \mathrm{C}$, persistent during the spring-summer-autumn period, and an average minimum of $11{ }^{\circ} \mathrm{C}$ during winter; the average annual relative humidity is $68 \%$, its maximum $98 \%$ and minimum 14\% (CIAD, 2018). It has dry tropical climatic conditions (BSl(h')w(w)(e)) (Garcia, 2004) and an estimated 493,164 head of cattle are annually housed in feedlots, where 106,289 t are produced, it is equivalent to $5.4 \%$ of the national beef production. Renaudeau $e t$ al. (2012) state that the decrease in cattle production indicators in hot regions is affected by several factors. The main one is heat stress, which is generated by high environmental temperatures; this thermal condition occurs once the environmental temperature exceeds the cattle's thermo-neutral zone, which prevents them from dissipating the extra heat (Bernabucci et al., 2010). Therefore, the objective of this research was to review heat stress mitigation strategies in intensive cattle feedlots in the dry tropical region of Mexico.

\section{What is stress?}

The biological expression of stress has been used as an indicator of the loss of animal welfare (Broom, 2003) and is defined as the action of sensory and emotional stimuli provoked by the environment on the nervous, endocrine, circulatory and digestive systems of an animal (Broom, 2005). It is referred to as distress when the animal's response to the stressor causes risks to its well-being and life (Mormède et al., 2007).

\section{Physiological response to heat stress}

The body temperature of cattle can vary from 37.8 to $40{ }^{\circ} \mathrm{C}$; within this range, their organism efficiently fulfills its cellular and biochemical functions, due to this, they need to generate or dissipate heat towards the environment; when they face diverse environmental conditions to which they are not adapted, they tend to alter their physiological, behavioral and productivity mechanisms, to maintain their body temperature (Arias et al., 2008). For this reason, thermoregulation mechanisms are activated (Sanmiguel and Avila, 2011). Several studies have established that cattle perform better in the thermoneutral zone of $20^{\circ} \mathrm{C}$, which varies between 10 to $26^{\circ} \mathrm{C}$; but when the temperature exceeds $27^{\circ} \mathrm{C}$, especially if relative humidity exceeds $40 \%$. Then, they begin to have difficulties to self-regulate and heat stress is triggered, which manifests as reduced feed intake and consequently lower weight gain (Mader et al., 2007; Lagos et al., 2014). Due to the environmental temperature being above the comfort zone, the heat load causes cattle not to dissipate heat without additional energy expenditure to maintain corporal temperature; this generates physiological and behavioral responses to ease the effect of heat stress (Bernabucci et al., 2010). Both respiratory rate and panting are appropriate indicators to assess the intensity of heat stress experienced by cattle (Brown-Brandl et al., 2005; Gaughan and Mader, 2014).

\section{Heat stress, an approach to beef production}

To reduce heat load in high-temperature conditions, cattle tend to reduce heat production through voluntary anorexia, since fermentation of the rumen and digestion generates heat (Cedeño, 2011); which consequently decrease energy consumption, a 
negative energy balance is generated, which partially explains their weight loss and end up with a poor body condition when subjected to heat stress (Muñoz et al., 2013). Valente $e t$ al. (2015) mention that cattle of breeds specialized for meat production tend to decrease in $24 \%$ their dry matter consumption during the day under heat stress conditions, reducing metabolic heat production; consequently, water consumption increases their physiological response to decrease body temperature. Pereyra et al. (2010) observed that the frequency to access water also increases; though, cattle appear to drink, but do not do so, due to a decrease in their body activities, including feed intake and walking. With rumination decreased, increased respiratory rate and panting, the concentration of $\mathrm{HCO}_{3}$ decreases, generating the risk of ruminal acidosis, affecting weight gain and consequently feed conversion (Malafaia et al., 2011).

To increase the heat loss through evaporation, the respiratory rate increases under heat stress conditions (Morais et al., 2008; Bernabucci et al., 2010). Research has shown that Angus cattle have elevated respiratory rate, even in comfort temperatures, due to the demanding rate of weight gain, which implies an extraordinary metabolic activity and consequently metabolic heat production gets elevated (Valente et al., 2015). Cattle under heat stress tend to lose more saliva and minerals such as sodium and potassium, besides the potential ruminal acidosis due to the excessive saliva loss effect (Hall, 2000). These conditions negatively impact the productive indicators and consequently generates economic losses for the beef industry (O’Brien et al., 2010; Renaudeau et al., 2012).

\section{Temperature and relative humidity index: effect on caloric load}

Thom published in 1959 a famous formula to calculate a thermal discomfort index based on the ambient temperature and relative humidity, focused on the human population. Similarly, the effect of climate on animal production has been highly studied, achieving important advances to understand physiological and behavioral aspects of animal behavior under climatic stress conditions, by jointly evaluating factors such as solar radiation, relative humidity, ambient temperature, wind speed and rainfall; together, these variables have a direct effect on animal welfare (Mitloehner et al., 2001; Brown-Brandl et al., 2006). Mader et al. (2006) applied the following equation to assess heat stress in feedlot beef cattle:

$$
I T H=0.8 * \text { ambient temperature }+(\% \text { relative humidity } \mid 100) *(\text { air temperature }-14.4)+46.4
$$

and used the Livestock Weather Safety Index (LWSI), published by LCI in 1970, as a reference to assign heat stress levels to the following categories: Comfort, $\leq 74$; Alert, $74<$ ITH $<79$; Danger, $79 \leq \mathrm{ITH}<84$; and Emergency, ITH $\geq 84$. In this way, the temperature and humidity index are indicators used to measure the heat stress degree to which cattle are subjected (Gaughan et al., 2008; Olivares et al., 2013).

\section{Climatic conditions at Guliacán valley}

Table 1 shows a summary of the climatic variables frequently recorded throughout the months in the valley of Culiacán, Sinaloa, México. 
Table 1. Annual summary of climatic variables in the Culiacán valley, Sinaloa.

\begin{tabular}{l|c|c|c|c|c|c|c|c}
\multicolumn{1}{c}{ Month } & $\begin{array}{c}\text { T Min } \\
\left({ }^{\circ} \mathbf{G}\right)\end{array}$ & $\begin{array}{c}\text { T Max } \\
\left({ }^{\circ} \mathbf{G}\right)\end{array}$ & $\mathbf{R H},(\%)$ & $\begin{array}{c}\text { THI } \\
\mathbf{M i n}\end{array}$ & $\begin{array}{c}\text { THI } \\
\mathbf{M a x}\end{array}$ & $\mathbf{U V}$ & Light $(\mathbf{h})$ & Sun $(\mathbf{h})$ \\
\hline January & 10.9 & 27.8 & 72 & 52.6 & 78.3 & 5 & 10.8 & 6.1 \\
\hline February & 11.3 & 28.9 & 70 & 53.3 & 79.7 & 7 & 11.4 & 6.7 \\
\hline March & 12.1 & 30.5 & 67 & 54.5 & 81.6 & 10 & 12.0 & 7.4 \\
\hline April & 14.5 & 32.8 & 65 & 58.1 & 84.6 & 11 & 12.8 & 7.1 \\
\hline May & 18.0 & 34.9 & 64 & 63.1 & 87.4 & 12 & 13.4 & 8.0 \\
\hline June & 23.2 & 35.9 & 67 & 70.9 & 89.5 & 12 & 13.7 & 7.4 \\
\hline July & 24.1 & 35.5 & 72 & 72.7 & 90.0 & 12 & 13.5 & 6.2 \\
\hline August & 23.8 & 34.8 & 75 & 72.5 & 89.5 & 12 & 13.0 & 6.4 \\
\hline September & 23.6 & 34.4 & 75 & 72.2 & 88.9 & 11 & 12.3 & 6.5 \\
\hline October & 20.7 & 34.2 & 72 & 67.5 & 88.0 & 9 & 11.6 & 7.4 \\
\hline November & 15.6 & 31.5 & 71 & 59.7 & 83.7 & 6 & 10.9 & 7.1 \\
\hline December & 12.2 & 28.2 & 72 & 54.6 & 78.9 & 5 & 10.6 & 5.9 \\
\hline
\end{tabular}

T: ambient temperature in degrees Celsius; RH: relative humidity in percent; THI: temperature and humidity index; UV: ultraviolet radiation.

The maximum average value of THI indicates that, during winter, cattle are in distress, and from spring to fall in emergency conditions (Table 2). Heat stress is associated with reduced productivity and animal welfare, especially during the summer months (Lees et al., 2019).

Table 2. Heat stress categories for animals in production established by the World Meteorological Organization (1989).

\begin{tabular}{c|c|l}
\hline THI & Categories & \multicolumn{1}{c}{ Interpretation } \\
\hline$<70$ & Confort & Suitable conditions, the animal is not under any heat stress. \\
\hline $71-79$ & Alert & $\begin{array}{l}\text { Approaching the critical limit of production; prepare to } \\
\text { take precautions, do not leave animals exposed to the sun. }\end{array}$ \\
\hline $80-83$ & Danger & $\begin{array}{l}\text { Above the critical limit of production; do not subject the } \\
\text { animals to too many movements. }\end{array}$ \\
\hline$>84$ & Emergency & $\begin{array}{l}\text { Extreme heat stress conditions in production; minimize any } \\
\text { activity, activities should be done during the morning. }\end{array}$ \\
\hline
\end{tabular}

Therefore, it is considered necessary to establish mitigation measures to ease the heat stress consequences.

\section{Heat stress mitigation measures}

To maintain body temperature, cattle need to gain or lose heat from their surrounding environment; this process, called heat balance, is achieved through a constant thermoregulation process that involves the flow of heat through four basic pathways: conduction, convection, radiation and evaporation. When the physiological mechanisms to maintain thermoneutrality are not sufficient, the animal enters what is known as the heat stress zone (Beatty et al., 2006). Cattle can subsist in adverse climatic conditions, for which, various individual characteristics are involved; however, there are geographical areas, such as tropical regions, where mitigation measures need to be implemented. One 
of the main mitigation measures is shading feedlots, which reduce the impact of solar radiation and heat load by up to 30\% (Brown-Brandl et al., 2013). To avoid the excess heat effects, cattle also modify their usual behavior; under heat stress conditions they decrease the time spent consuming feed and lying down, increase the time spent drinking water and standing near water troughs; or places with better ventilation (Arias et al., 2008). If their body temperature reaches a critical level, the animals may die due to the lack of control over the regulation of this physiological indicator (Renaudeau et al., 2012). In this matter, Gaughan and Mader (2014) observed that panting is a heat stress indicator in cattle. In this regard, several authors indicate that shading helps to mitigate heat stress; Mitlöhner et al. (2001), Mitlöhner et al. (2002), Gaughan et al. (2010), Blaine and Nsahlai (2011) and Sullivan et al. (2011) agree that shade availability helps cattle to mitigate heat load.

\section{Availability of shade in feedlots}

Providing shade in intensive beef cattle finishing pens influences the reduction of direct or indirect losses in livestock (Brown-Brandl et al., 2005). Renaudeau et al. (2012) indicated that shade usage helps to mitigate heat stress; similarly, Mitlöhner et al. (2001) noted that cattle housed under the shade provided by $80 \%$ solar filtering (FS) polypropylene fabric at a $3 \mathrm{~m}$ height, had lower respiration rate, as well as higher feed intake and higher weight gain, reaching finishing weight 20 days earlier than cattle without access to shade. Blaine and Nsahlai (2011), in South Africa during the winter season, provided $2.87 \mathrm{~m}^{2}$ of shade per head, from corrugated iron sheeting, placed at a $5 \mathrm{~m}$ height. They observed that cattle housed in shade obtained higher final weight than those housed without shade, as well as higher weight gain and improved feed conversion; also, the carcass weight difference was higher; they also indicated a panting decrease and increased resting time. In Australia, Angus steers were provided with a $3.3 \mathrm{~m}^{2}$ shade per bovine, with a black polypropylene fabric at $80 \%$ FS at $4 \mathrm{~m}$ height. Gaughan et al. (2010) observed lower body temperature and panting in animals housed with shade, as well as higher CMS, GDP, finishing weight and hot carcass weight. Sullivan et al. (2011) assessed the shade availability (0, 2.0. 3.3 and $4.7 \mathrm{~m}^{2}$ /animal) provided by $70 \%$ black FS solar fabric at $4 \mathrm{~m}$ height; it shows that shade-providing improved animal welfare and performance, while different areas of shade/ bovine did not affect productive variables, but shades greater than $2.0 \mathrm{~m}^{2}$ improved bovine welfare. In a tropical climate, Castro et al. (2020) determined that increasing shade space in feedlots tends to linearly increase the average of daily gain and dry matter intake; this effect was more evident between 1.2 and $2.4 \mathrm{~m}^{2}$ of shade/head.

The recommended shade space is $3.7 \mathrm{~m}^{2}$ in adult animals (Gasque, 2008); the shade height should be at least $4 \mathrm{~m}$ so that it does not interfere with air movement and thus achieve greater projection inside the pen; a strategy to keep the floor of the pen dry is to leave unshaded spaces of $15 \mathrm{~cm}$ in the structure (Lagos et al., 2014).

\section{Feeding space}

While feeding cattle tend to show hierarchical behavior, because those of higher rank fed first (Méndez et al., 2013); the required space may vary between young animals and large animals; for young animals, a linear space of $0.45 \mathrm{~m}$ per head is required, 
and larger than $300 \mathrm{~kg}$ animals require 0.70 to 0.90 linear m per animal (Gasque, 2008; Lagos et al., 2014).

\section{Drinking trough space requirements}

Water troughs are an important part of feedlots, since they provide fresh, clean water in necessary quantities, so the required size of water troughs is $30 \mathrm{~cm}^{2}$ per 10 bovines; these should not be deep, to avoid water stagnation and consequently its contamination, offering less freshwater for cattle (Lagos et al., 2014).

\section{Feedlot density}

It is important to take into account for the construction of the pens for intensive feedlots, cattle in production require a living space where they can express their natural behavior while remaining within the finishing cycle (Gasque, 2008); the required living space for fattening animals is of $18.5 \mathrm{~m}^{2}$ per animal, but this can be modified according to the animal's weight, requiring up to $15 \mathrm{~m}^{2}$ per animal when they weigh $300 \mathrm{~kg}$ or less, and $20 \mathrm{~m}^{2}$ per animal over $400 \mathrm{~kg}$; this is why, the number of cattle per pen should be established according to the $\mathrm{m}^{2}$ of available surface area in the feedlot (Lagos et al., 2014). The scientific information regards the effect of feedlot density and its relationship with the productive performance of cattle is limited; in this sense, Ha et al. (2018) researched the density and the productive response of cattle; in that research, the authors state that increasing the space per animal in feedlots can improve the cattle's welfare, since they can express their natural behavior, tend to increase their social behavior and decrease agonistic behaviors, which usually occur in pens with less living space per animal. In the aforementioned study, an improvement in carcass characteristics, such as rib-eye area (REA) and marbling percentage, was also observed; in another study, conducted by Lee $e t$ al. (2012), they reported that a low density per pen helps cattle grow faster, obtain larger REA, improve feed efficiency, GDP and improve carcass weight.

\section{CONGLUSIONS}

Heat stress mitigation strategies in beef cattle in intensive finishing under practical conditions should contribute to animal welfare and improve productivity indicators in the Mexican dry tropics. Heat stress mitigation strategies in beef cattle under intensive finishing directly contribute to productive indicators and animal welfare in the Mexican dry tropics.

\section{REFERENGES}

Arias, R.A., Mader, T.L., \& Escobar, P.C. (2008). Factores climáticos que afectan el desempeño productivo del ganado bovino de carne y leche. Archivos de Medicina Veterinaria 40 (1): pp.7-22. DOI: 10.4067/S0301-732X2008000100002

Beatty, D.T., Barnes, A., Taylor, E., Pethick, D., McCarthy, D.M. \& Maloney, S.K. (2006). Physiological responses of Bos taurus and Bos indicus cattle to prolonged, continuous heat and humidity. Journal of Animal Science, 84 (4):pp.972-985. DOI: 10.2527/2006.844972x.

Bernabucci, U., Lacerera, N., Baumgard, L. H., Rhoads, R. P., Ronchi, B., \& Nardone, A. (2010). Metabolic and hormonal acclimation to heat stress in domesticated ruminants. Animal: An International Journal of Animal Bioscience, 4(7): pp.1167-1183. DOI: 10.1017/ S175173111000090X

Blaine, K. L., \& Nsahlai I. V. (2011). The effects of shade on performance, carcass classes and behaviour of heat-stressed feedlot cattle at the finisher phase. Tropical Animal Health Production, 43 (3):pp.609-615. DOI: 10.1007/s11250-010-9740-x 
Broom, DM. (2003). Transport stress in cattle and sheep with details of physiological, ethological and other indicator. Dtsch Tierârztl Wochenschr 110 (3): pp.83-89.

Broom, DM. (2005). The effects of land transport on animal welfare. Revue Scientifique et Technique 24(2): pp.683-691.

Brown-Brandl, T. M., R A Eigenberg, \& J A Nienaber. (2010). Benefits of providing shade to feedlot cattle of different breeds. 2010 Pittsburgh, Pennsylvania, June 20 - June 23, 2010. St. Joseph, MI: American Society of Agricultural and Biological Engineers Disponible en:https:// elibrary.asabe.org/abstract.asp?aid=43976

Brown-Brandl, T. M., Eigenberg R. A., Nienaber J. A., \& Hahn G. L. (2005). Dynamic response indicators of heat stress in shaded and non-shaded feedlot cattle, part 1: analyses of indicators. Biosystems Engineering 90(4): pp.451-462. DOI: 10.1016/j.biosystemseng.2004.12.006

Brown-Brandl, T. M., Nienaber J. A., Eigenberg R. A., Mader T. L., Morrow J. L., \& Dailey J. W. (2006). Comparison of heat tolerance of feedlot heifers of different breeds. Livestock Science, 105: pp.19-26. DOI: 10.1016/j.livsci.2006.04.012

Castro-Pérez, B.I., Estrada-Angulo, A., Ríos-Rincón, F.G., Núñez-Benítez, V.H., Rivera-Méndez, G.R., Urías-Estrada, J.D., Zinn, R.A., Barreras, A., \& Plascencia, A. (2020). The influence of shade allocation or total shade plus overhead fan on growth performance, efficiency of dietary energy utilization, and carcass characteristics of feedlot cattle under tropical ambient conditions. Asian-Australasian Journal of Animal Sciences. 33 (6): pp.1034-1041. Doi: 10.5713/ajas.19.0112

Cedeño, J. (2011). Efecto del estrés calórico en el bienestar animal, una revisión en tiempo de cambio climático. Espamciencia. 2 (1): pp.15-25.

CIAD. (2018). Sistema estadístico del clima automatizado de Sinaloa. Disponible en:http://187.141.135.166/CIAD/DatosPorMes.aspx

FIRA. (2019). Panorama agroalimentario: carne de bovino 2019. Disponible en: https://www.fira.gob.mx/InvYEvalEcon/EvaluacionIF.

García, E. (2004). Modificaciones al sistema de clasificación climática de Köppen. Universidad Nacional Autónoma de México. México. ISBN: 970-32-1010-4.

Gasque, G. R. (2008). Enciclopedia bovina. Editorial Universidad Nacional Autónoma de México. México, D.F. 437p. ISBN: 978-970-32-4359-4.

Gaughan, J. B., Bonner S., Loxton I., Mader T. L., Lisle A., \& Lawrence R. (2010). Effect of shade on body temperature and performance of feedlot steers. Journal of Animal Science, 88 (12): pp.4056-4067. DOI:10.2527/jas.2010-2987

Gaughan, J. B., \& Mader T. L. (2014). Body temperature and respiratory dynamics in un-shade beef cattle. International Journal of Biometeorology. 58 (7): pp.1443-1450. DOI: 10.1007/s00484-013-0746-8

Gaughan, J. B., Mader, T. L., Holt, S. M., \& Lisle, A. (2008). A new heat index for feedlot cattle. Journal of Animal Science, 86 (1): pp.226-234. DOI: $10.2527 /$ jas.2007-0305

Ha, J. J., Yang K. L., Oh D. Y., Yi J. K., \& Kim J. J. (2018). Rearing characteristics of fattening Hanwoo steers managed in different stocking densities. Asian-Australasian Journal of Animal Sciences, 31 (11): pp.1714-1720. DOI: 10.5713/ajas.17.0451

Hall, M. (2000). Meet the challenges of heat stress feeding. Howard's dairyman. May. 2000. pp. 344.

Lagos, G. H., González G. F. J., \& Castillo R. F. (2014). Paquete tecnológico para la engorda de ganado bovino en corral. Disponible en: http:// biblioteca.inifap.gob.mx

LCI. (1970). Patterns of transit losses. Livestock Conservation, Inc., Omaha, NE.

Lee, S. M., Kim J. Y., \& Kim E. J. (2012). Effects of stocking density or group size on intake, growth, and meat quality of Hanwoo steers (Bos taurus coreanae). Asian-Australasian Journal of Animal Sciences, 25(11): pp.1553-1558. DOI: 10.5713/ajas.2012.12254

Lees, A.M., Sejian, V., Wallage, A.L., Steel, G.C., Mader, T.L., Lees, J.C., \& John B. Gaughan, J.B. (2019). The impact of heat load on cattle: review. Animals: An Open Access Journal from MDPI. 9(6): p.322. DOI: 10.3390/ani9060322

Mader, T.L., Davis, M.S., \& Brown-Brandl, T. (2006). Environmental factors influencing heat stress in feedlot cattle. Journal of Animal Science, 84 (3): pp.712-719. DOI: 10.2527/2006.843712x

Mader, T., \& Colgan S. L. (2007). Pen density and straw bedding during feedlot finishing. Nebraska Beef Cattle Reports. University of NebraskaLincoln. Disponible en:https://digitalcommons.unl.edu/animalscinbcr/70/

Magaña, M.M.A., Leyva, M.C.E., Solís, A.J.F. \& Leyva, P.G.G. (2020). Indicadores de competitividad de la carne bovina de México en el mercado mundial. Revista Mexicana de Ciencias Pecuarias, 11 (3): pp.669-685. Doi: 10.22319/rmcp.v1 li3.5798

Malafaia, P., Barbosa J. D., Tokarnia C. H., \& Oliveira C. M. C. (2011). Distúrbios comportamentais em ruminantes não associados a doenças: origem, significado e importancia. Pesquisa Veterinária Brasileira 31(9): pp.781-790. DOI: 10.1590/S0100-736X2011000900010

Méndez, M. R. D., Schunemann A. A., Rubio L. M. S., \& Braña V. D. (2013). Bienestar animal para operarios en rastro de bovinos. INIFAP. Querétaro. 58 p. ISBN: 978-607-37-0091-7

Miltlöhner, F. M., Morrow J. L., Dailey J. W., Wilson S. G., Galyean M. L., Miller M. F., \& McGlone J. J. (2001). Shade and water misting effects on behavior, physiology, performance, and carcass traits of heat-stredded feedlot cattle. Journal of Animal Science, 79 (9): pp.2327-2335. DOI: $10.2527 / 2001.7992327 x$

Mitlöhner, F. M., Galyean M. L., \& McGlone J.J. (2002). Shade effects on performance, carcass traits, physiology, and behavior of heat-stressed feedlot heifers. Journal of Animal Science, 80 (8): pp.2043-2050. DOI: 10.2527/2002.8082043x

Morais, D. A. E. F., Maia A. S. G., Silva R. G., Vasconcelos A. M., Oliveira L. P., \& Guilhermino M. M. (2008). Variação anual de hormônios tireoideanos e características termorreguladoras de vacas leiteiras em ambiente quente. Revista Brasileira Zootecnia, 37(3): pp.538-545. DOI: 10.1590/S1516-35982008000300020.

Mormède, P., Andanson, S., Aupérin, B., Beerda, B., Guémené, D., Malmkvist, J., Manteca, X., Manteuffel, G., Prunet, P., Van Reenen, C., Richard, S., \& Veissier, I. (2007). Exploration of the hypothalamic-pituitary-adrenal function as a tool to evaluate animal welfare. Physiology and Behavior 92 (3): pp.317-339. DOI: 10.1016/j.physbeh.2006.12.003.

Muñoz, J., Gómez, A., Rojas, G., Orjuela, J., \& Valencia, A. (2013). Determinación de la incidencia de estrés calórico en número de nacimientos en bovinos doble propósito del departamento de caqueta. REDVET. 14(7). 
O’Brien, M. D., Rhoads, R. P., Sanders, S. R., Duff, G. C., \& Baumgard, L. H. (2010). Metabolic adaptations to heat stress in growing cattle. Domestic Animal Endocrinology, 38 (2): pp.86-94. DOI: 10.1016/j.domaniend.2009.08.005.

Olivares, B. O., Guevara, E., Oliveros, Y., \& López, L. (2013). Aplicación del índice de confort térmico como estimador del estrés calórico en la producción pecuaria de la esa de Guanipa, Anzoátegui, Venezuela. Zootecnia Tropical 31: pp.209-223.

Pereyra, A. V. G., Maldonado, M. V., Catracchia, G. G., Herrero, M. A., Flores, M. C., \& Mazzini, M. (2010). Influence of water temperature and heat stress on drinking water intake in dairy cows. Chilean Journal of Agricultura Research. 70 (2): pp.328-336. Doi: 10.4067/S071858392010000200017

Renaudeau, D., Gollin A., Yahav S., Basilio V., Gourdine J. L., \& Collier R. J. (2012). Adaptation to hot climate and strategies to alleviate heat stress in livestock production. Animal 6(5): pp.707-728. DOI: 10.1017/S1751731111002448.

Rubio, M. S., Braña, D., Méndez, R. D. \& Delgado, E. (2013). Sistemas de producción y calidad de carne bovina. Folleto técnico No. 28. Facultad de Medicina Veterinaria y Zootecnia. Universidad Nacional Autónoma de México. Centro Nacional de Investigación Disciplinaria en Fisiología y Mejoramiento Animal. INIFAP. Ajuchitlán. Colón. Querétaro. Folleto técnico No. 28. P: 4-56.

SADER-SIAP. (2019). Servicio de información agroalimentaria y pesquera. Producción ganadera. Disponible en: https://www.gob.mx/siap/ acciones-y-programas/produccion-pecuaria

Sanmiguel, P. R. A., \& Ávila, V. D. (2011). Mecanismos fisiológicos de la termorregulación en animales de producción. Revista Colombiana de Ciencia Animal 4(1): pp.88-94.

Sullivan, M. L., Cawdell-Smith, A. J., Mader, T. L., \& Gaughan, J. B. (2011). Effect of shade área on performance and welfare of short-fed feedlot cattle. Journal of Animal Science 89: pp.2911-2925. DOI: 10.2527/jas.2010-3152

Thom, E.C. (1959). The discomfort index. Weatherwise 12: pp.57-59. Doi: 10.1080/00431672.1959.9926960

Valente, É. E. L., Chizzotti M. L., Ribeiro O. G. V., Castlho G. M., Domingues S. S., Castro R. A., \& Machado L. M. (2015). Intake, physiological parameters and behavior of Angus and Nellore bulls subjected to heat stress. Semina: Ciências Agrárias, Londrina. 36(6): pp.4565-4574. DOI: $10.5433 / 1679-0359.2015 v 36 n 6$ Supl2p4565

WMO. (2010). Guide to agricultural meteorological practices. World Meteorological Organization. Disponible en: http://www.wmo.int/pages/ prog/wcp/agm/gamp/documents/WMO_No134_en.pdf 